\title{
Contesting 'Deforestation': Civil Society Movements and Knowledge Co-Production in Indonesia ${ }^{1}$
}

\author{
Maharani Hapsari
}

Received: 30 January 2017 | Accepted: 26 March 2018 | Published: 3 May 2018

\begin{abstract}
This article explains the emergence of civil society movements around deforestation issue in Indonesia as contestation over knowledge claims that defines 'deforestation' as a political term. The term 'deforestation', which is translated into 'perusakan hutan' in Indonesian forestry laws and regulation, is a product of political epistemology that serve the needs to sustain state-reinforced developmentalism. It is imposed by valorization of modern scientific and technocratic values as well as bureaucratization of the forestry sector. Engaging with critical political ecology literatures, this study unpacks the constitutive interactions among various ways of seeing that redefine state forestry and its implications to the reproduction of political order. 'Perusakan hutan' is continuously re-negotiated in the relations between the state and its formative societal elements. Knowledge on addressing deforestation is organized around three contesting epistemologies: conservation, redistribution, and indigeneity. Each epistemology seeks to claim political influence in the institutionalization of knowledge that fortifies state's policies in the forestry sector. Politics of knowledge co-production operates at two levels: between hegemonic knowledge construct and its counter knowledge formation, and within the formation of counter-knowledge through alternative epistemologies.
\end{abstract}

Keywords: knowledge co-production; political epistemology; Indonesia; deforestation; civil society movements; environmentalism

\section{Introduction}

The surge of civil society movements and its implications environmentalism in Indonesia has been subject to scholarly debates. Previous research were assembled upon the organization

Author is lecturer of Department of International Relations, Faculty of Social and Political Science, Universitas Gadjah Mada. Author would like to thank Ely Susanto (Universitas Gadjah Mada) and Ian Wilson (University of Murdoch) for constructive comments during draft writing, and Krisdyatmiko (Universitas Gadjah Mada) for participating in this research program. Author would also like to thank Agustinus Moruk Taek, Suparlan, Nanik Lestari, and Ahmad Rijensa Akbar for their extensive contribution during data collection. 
of political economic interests (where access and control over environmental resources are contested), ethics (nature's protection, social justice, and human rights), governance and legal reform (political decentralization, corruption, regional autonomy), as well as democracy and citizenship (among others include issues such as participation, political recognition, and civic activism). The globalizing Indonesia's forest was increasingly recognized, portraying the interplay between domestic and international dimensions that shape the commodification of forest resources. The dynamics of civil society movements were explained in relation to conflicts and fragmentations that shape the reconfigurations of state power, where ideas, institutions, and political interests evolves over time (Kurniawan \& Rye, 2014; Okamoto, 2001; Nomura, 2007). Political differentiation is captured at various levels of political struggles, types of issues being advocated, strategies of representation and political articulation (Karimasari, 2011), and the involvement of transnational mobilization (Kurniawan \& Rye, 2014; Di Gregorio, 2011).

What this study raises is lack of attention to epistemological differences that inform civil society movements as they construct political issues. Environmental problems were constructed based on different worldviews and experiences, informed by different knowledge foundations, led to different policies, and brought different impacts to political constituents. It questions the seemingly unproblematic definition of 'deforestation' as a policy term in government regulations, policy documents of various organizations (Suwarno, Hein, \& Sumarga, 2015; Spilsbury, 2010), as well as in the political strategies developed by civil society organizations. This has led to the depoliticization of the movements as a subject of power struggle. Current definition of 'deforestation' adopted by the government is a product of power contestation among different epistemologies that seeks authorization from the state in the national law and other relevant legal documents. Control over particular definition by political groups also means control over 
further political orientation that these particular groups need to secure.

This study examines the formation of civil society movements around deforestation as politicization of collective knowledge marked by epistemological differences. Movements are seen as deliberative collective knowledge making project and the struggle for legitimate knowledge claim. The term 'deforestation' is fabricated in the struggle among diverse knowledge representations. Examining the interplay among different knowledge will help to make sense the political aspects of epistemological diversity within civil society movements. Questions addressed here include how different conceptions of 'deforestation' came about, what particular ways of seeing inform the process and how do they relate to the evolving political interests, what does defending particular epistemological position mean for civil society actors as they engage in collective action, and how political dynamics within the movements situate particular epistemology more legitimate than others in the configuration of state-enforced knowledge.

The politics of defining 'deforestation' is described as one that involves the production of an object of political governance. It aims to explain the emergence of anti-deforestation movements as contestation among different epistemologies in the relations between human society and forest. An engagement with critical political ecology literatures provide a useful basis to conceptualize the link between knowledge and environmental politics under the term 'the politics of environmental epistemology' (or, what we know about environment, with whose inputs, and with what effects). ${ }^{2}$ Discussions are mapped around 'deforestation' as a term attached to particular political epistemology and how it is purposeful for mobilizing power struggle and transforming power relations, particularly between the

Epistemology is defined here as the theory of knowledge. A crucial problem is establishing criteria for defining when we know, and do not know, something. Epistemological questions are concerned with what sort of information is meaningful, who is recognized as speaking with accuracy, and who decides both of these questions (See Forsyth, 2003) 
state and its transforming powers. ${ }^{3}$ Three epistemological traditions and their political orientations are to be discussed here: conservation, ${ }^{4}$ redistribution, ${ }^{5}$ and indigeneity. ${ }^{6}$ Such typology is developed from data categorization. It considers the converging political orientation represented by civil society movements groups informed by specific ways of knowing deforestation as socio-ecological problem. Three epistemological traditions also reflect how environmentalism is

Forsyth introduced the importance of environmental epistemology in response to Piers Blaikie and his collaborators' writing on political ecology during 1980s that attempts to correct social injustices, but was considered under-politicized. Forsyth, however, highlighted the transitional thinking in subsequent works Blaikie and his collaborators developed since 1990s which reflected two broader changes in political ecology: the role of environmental discourse and narratives and an increased awareness of the limits of ecological notions of stability and equilibrium that underlie many popular narratives of environmental change and crisis (Forsyth, 2008).

4 'Conservation knowledge' refers to the emerging knowledge that focus on the creation of territorially based conservation policies; the creation of protected areas (see Vaccaro, Beltran, \& Paquet, 2013). The organization of conservation knowledge is associated with conservation science, which posits five axioms. The first one is there is no such a 'pristine nature'. It acknowledges that an understanding that conservation centered on areas free of people is socially unjust. Conservation efforts, therefore, will focus increasingly on areas already inhabited by human or are affected by human activities. Second, nature also merits conservation for very practical and more self-centered reasons concerning what nature and healty ecosystems provide to humanity. Third, nature has its own resilience. Fourth, in order to avoid tragedy of the commons, the only ways to practice conservation are to enact strict regulations and restrictions or to simply buy and protect the resource directly. Fifth, local conservation efforts are deeply connected to global forces, which needs to be scrutinized (see Kareiva \& Marvier, 2012). The formation of conservation knowledge often works along what Haenn described as the porous boundaries between middle class conservationist and non-capitalist peasants, implying a process of cultural sharing between these groups in defining political interest (see Haenn, 2016).

5 The term 'redistributive knowledge' here describes an association with the struggle for agrarian justice (see Borras Jr, 2006). It emphasizes critics to private ownership that is often claimed as a prerequisite to state-sponsored welfare projects under capitalist economy narrative.

6 The term 'indigenous knowledge' is often positioned againts 'modern knowledge' or scientific knowledge'. According to Banuri and Apfell-Marglin (as cited in Agarwal, 1995, p. 425): Traditional knowledge systems are embedded in the social, cultural and moral milieu of their particular community. In other words, actions or thoughts are perceived to have social, political, moral and cosmological implications, rather than possessing only, say, a purely technological dimension. By contrast, the modern system of knowledge seeks to distinguish very clearly between these different dimensions. Technical questions pertain to cause-and-effect relationships in the natural environment, and can coexist with many different social, moral, political or cosmological contexts. The term 'indigenous' is not merely categorical, but it reflects a continuous rejection to and an attempt to exclude the idea of scientific knowledge embedded in the idea and practices of the modern state. The state is seen as a 'foreign power' and its implications to the 'indigenous', 'customary', and 'local'. Recognition of the state, therefore, is seen as mutually constitutive with recognition of customary communities $(\mathrm{Li}, 2001)$. 
produced in the plural relations between these groups and forest as ecological system, bearing in mind that deforestation is socially constructed in the reorganization of power in Indonesia.

Data was collected through in-depth interviews and focus group discussions in June and July 2016 with 27 respondents representing 14 organizations in Jakarta, Bogor, Pontianak and Palangkaraya. These respondents represent environmental activists, farmers, academia, and mass media correspondents and journalists. A qualitative analysis was employed to document different experiences of these actors in accumulating, consolidating and disseminating knowledge to wider political audience.

Discussions are organized into four sections. The first section discusses the conceptual links between knowledge, political epistemology and social movements. The second section discusses the construction of 'perusakan hutan' as a way of seeing 'deforestation' reproduced through scientific forestry. It examines emblematic political economic interests that reinforce state developmentalism supported by elitist state policies and state corporatism. The third section explains the emergence of civil society movements with their formative political knowledge: conservation, redistribution and indigeneity, and how they position themseves in relation to state-enforced 'deforestation'. The fourth section explains how coproduction works in the alliances of epistemic groups as they struggle to maintain the boundaries of their particular epistemological position while at the same time developing critical engagement across state-society domains.

\section{Knowledge, Political Epistemology and Civil Society Movements}

The importance of knowledge has been recognized as a dimension of contemporary political mobilization in new social movements research. Leach and Scoones, argued that "there is a tendency for social and political disputes to become technical disputes, and for conflicts around resources to be expressed in terms 
of conflicts around knowledge" (Leach \& Scoones, 2007). Boudia and Jas illustrated that in the case of dealing with environmental toxic, the mobilization of scientific knowledge and expertise was always central to transform the regulatory system. At the same time, knowledge also interacts with the growing environmentalism around issues of health and toxicity, accumulating in the production of scientific knowledge and counter-expertise (Boudia \& Jas, 2014).

Deforestation is an epistemic problem, what Turner defined as a problem of the aggregation of distributed knowledge for the purpose of making decisions, or 'political epistemology' (Turner, 2007, p.41). When defining 'the political', Schmitt argued that: "words... are incomprehensible if one does not know exactly who is affected, combated, refutes, or negated by such terms" (Schmitt, 1967). The use of 'deforestation' in the reproduction of state-backed science and bureaucratic knowledge is a process that deliberately excludes other knowledge commitments.

Power structuring around the definition of 'deforestation' in Indonesia is discussed here as a product of a political process termed as knowledge co-production (Jasanoff, 2004). The concept explains co-evolution of science and politics that leads to hegemonic environmental explanations of what deforestation is and its implications to power ordering. Co-production refers to "the simultaneous production of knowledge and social order" (Jasanoff, 2004). Contestation of knowledge, when read in this term, is a dynamic process that involves knowledge framing, collection and dissemination, which shape the struggle for enforced order (Jasanoff, 2004).

The role of scientific knowledge is prominent in the process of legitimizing modern, rational and bureaucratic forest management, especially in the formation of post-colonial nation-states. In many countries where modern forest management is implemented, the presence of technocratic institutions and personnels is supported by strong state authority and apparatus to govern the utilization of natural resources. Knowledge co-production is useful to see how 
knowledge stability in scientific forest management in Indonesia is created and maintained in the state ministry, state regulations, and research institutions. In the context of explaining the emergence of anti-deforestation movements in Indonesia, Jasanoff presented a strong claim that co-production are not content simply to ask what is; but also to understand how particular states of knowledge are arrived at and held in place, or abandoned (Jasanoff, 2004).

There were attempts to understand the link between knowledge and environmental movements. Boudia and Jas referred to three interdependent process: (a) a process that involves the established scientist who disseminate environmental facts and concerns in public and call for the implementation of prevention and remediation policies (b) the creation of new disciplines to promote new research subjects and approaches (c) the production of alternative knowledge beyond the two previous domains through participatory decision-making at domestic and international level (Boudia \& Jas, 2014). Leach and Scoones summarized four ways in which social movements engage with science:

(1) disputing scientific claims; (2) seeking to acquire a cachet of scientific authority for a political claim by finding a scientific expert to validate their political stance; (3) rejecting the scientific way of knowing and advancing their claims to expertise from some wholly different epistemological standpoint, and (4) attempting to 'stake out some ground on the scientists' own terrain' by questioning 'not just the uses of science, not just the control over science, but sometimes even the very contents of science and the processes by which it is produced (Leach \& Scoones, 2007, p.17).

Defining 'deforestation' is a political project involving how human beings reorganize ideas about reality under competing epistemologies. It emphasizes "knowledge conflicts within worlds that have already been demarcated, for practical purposes, into the natural and the social" (Jasanoff, 2004, p.19). Knowledge politics is understood as a product of contesting epistemologies that shape the interaction between counter hegemonic forces and state-enforced ways of seeing. 


\section{'Perusakan Hutan' as State-reinforced Term}

While the term 'deforestation' has been a subject of wide public debate, many might not be aware of the fact that Indonesian national forestry laws introduced after independence never formally adopted it. The government has used the term 'perusakan hutan' or 'forest destruction'. The first Forest Law, Law 5/1967, defined forest in association with land cover instead of land use. 'Forest' was defined as the area where trees are growing and constitutes a totality of natural biodiversity with all its environment and is designated by the government as forest. The government defined two categories of forest based on its status of property rights: state forest (which may include customary forest) and property forest. ${ }^{7}$

Law 41/1999 on Forestry introduced in the Post-New Order era adopted a similar definition as used in the Basic Forestry Law 1967. ${ }^{8}$ The government defined the legal respond to forest destruction within the scope of 'forest protection and natural conservation'. 'Forest protection' is defined as an effort to prevent and to limit forest destruction, forest zone, and forest products caused by human action, cattles, fires, natural forces, pests and diseases, as well as to maintain and protect states' rights, community rights and individual rights on forest, forest zone, and forest resources as well as investment and apparatuses relevant to forest management. ${ }^{9}$

Law 18/2013 on Prevention and Combating Forest Destruction defined 'forest' as a coherent landscape consisting of biodiversity dominated by the population of trees in the ecosystem, which cannot be separated one from each other. ${ }^{10}$ 'Forest zone', meanwhile, is defined as specially defined zone by the government

\footnotetext{
See Article 2

8 The law stated that forest shall be an integral unit ecosystem in the forms of lands containing biological resources, dominated by trees in their natural environment (See Article 1.2). 'Forest destruction' is defined as changes in the physical attributes as well as physical or biological characteristics, which led to disturbances of forest so it cannot deliver its function (see explanation of Article 50.2).

9 See Article 47

10 See Article 1.1.
} 
to be preserved as permanent forest. ${ }^{11}$ 'Forest destruction' is process, method or action to destroy forest through illegal logging, the use of forest zone without formal permits or utilization of forest land in contrast to the purpose and objectives of distributing permits within the forest zone, which has been stated, refereed to, or is being processed by the government. ${ }^{12}$

Territorial claim over forest has been exercised since the Dutch Colonial era. Here, scientific forestry ${ }^{13}$ is an effective political tool that produces authoritative claim over other forms of knowledge. Vandergeest and Peluso used the specific term of professional forestry to refer to the scientific and technocratic sense of forest governance practices by the Dutch, which was then also adopted in the Netherland East Indies. The role of German and French traditions of professional forestry was influential in training programs and education for officials and experts (Vandergeest \& Peluso, 2006).

Scientific forestry builds strong access and control of the state over land use, butressed with state extractivism (Peluso, 1992). The pre-existing expertise in managing forest land allowed the New Order State to execute industrialization in the forestry sector. Under state's hegemonic power, defining deforestation entails a fixation of knowledge that favors the larger roles of state foresters and state elites in the Ministry of Forestry over the vast track of land use. ${ }^{14}$

Scientific forestry is political machinary of New Order government that assembles the diverse knowledge centered on rationalization and utilization of forest resources to induce economic growth. ${ }^{15}$ Forest delineation policies produced larger

\footnotetext{
See Article 1.2.

See Article 1.3.

A detailed historical development of scientific forestry can be found in Perry (1998).

4 According to the Ministry of Forestry Decree on the Designation of Provincial Terrestrial Forest and Marine Coastal 2012, the total area in Indonesia is 321,891,993 hectares. As part of this figure, terrestrial forest accounts for 129,024,612 hectares of land under the authority of the Ministry of Forestry.

15 President Suharto enacted various state regulations that institutionalized the primacy of bureaucratic knowledge driven by strong developmentalist ideology. Three key
} 
political authority for state forestry agency vis a vis other sectorbased state ministries. ${ }^{16}$ Forest maps have also been an important tool of state land managers and supporting international institutions, such as FAO, the World Bank, Worldwide Fund for Nature, and the International Union for the Conservation of Nature (Peluso, 1995). Scientific forestry have overridden forest land use practices inherited by local communities from the pre-colonial era. This has led to grievances among the affected communities and to the emergence of social and tenurial conflicts (Barber, 1998). Access and control of marginalized groups over the utilization of forestland has been subject to state's reallocation of forestland. In response to this, marginalized communities have developed forest mapping to support their claim over forestland. ${ }^{17}$ As McCarthy argued, "while the state and adat regimes often compete to control the direction of social change, they also constantly make accommodations, and in some respects need to be considered as mutually adjusting, intertwined orders" (McCarthy, 2005: 57). ${ }^{18}$

Knowledge claims around the meaning of 'deforestation'

regulations issued by the New Order were Law 5/1967 on Forestry, Law 1/1967 on Foreign Investment, and Law 11/1968 on Domestic Investment, which allowed state-owned enterprises, private and foreign investors to gain access and control over business concessions in the forestry sector. Since then, forest concessions run by private corporations and conglomerates marked a common form of forest management in Java and Outer Islands, including Sumatra and Kalimantan. Industrialization of forest resources extraction became a major form of land use that strengthened the political relations between state elites and forestry businesses. This is particularly through state policies that serve the demand of global forest commodity market (timber and nontimber), which allows continuous accumulation of economic profit for state elites and their political clients (Peluso, 1995)

16 The role of other state ministries is limited to delegated authority by the Ministry of Forestry to use forest land for other purposes, for example infrastructure development projects, agriculture, and mining. At the same time, there has been a systematic exclusion of other forms of knowledge, particularly those developed by local communities.

17 Peluso, for example, using the term counter-mapping to describe a strategy by local communities to challenge in response to territorial claim by the state. Here, communities work with international organizations or engage with Indonesian NGOs who request the services of key international groups to learn the uses of counter-mapping strategies to document forest uses, claims and population distribution (Peluso, 1995).

18 McCarthy further referred to how local communities through customary institutions has been extremely adaptable by creating various coping strategies to sustain the livelihoods of its members (McCarthy, 2005). 
provides political advantages for hegemonic power, at the same time is part of political mobilization for counter powers. Reproduction of scientific forestry knowledge is taking place through strengthening expertise of foresters at both central and local levels of government. ${ }^{19}$ Close relations with international organizations who provides research funds and facilities allow national foresters to accrue benefit from international knowledge networks, ${ }^{20}$ which has increased political leverage of state bureaucrats.

\section{Altering 'Perusakan Hutan': Three Contending Epistemologies}

Although the term 'perusakan hutan' seems to dominate state's lexicon when interpreting 'deforestation', it does not mean other ways of seeing are absolutely excluded. In playing their antagonism with state's definition of 'deforestation', civil society actors engage in constitutive processes and translate different epistemologies in the movements into different forms of political activism. 'Deforestation' is redefined in many aspects of civil society struggles through political mobilization around three contesting political epistemology: conservation, redistribution, and indigeneity. ${ }^{21}$

\section{Conservation}

Conservationist organizations such as Greenpeace and WWF build political activism on the basis of conservation science and

19 The relationship between the forest department and the civil administration was also crucial because the civil service was almost always very influential both in central policy-making and in the local administration. As Vandergeest and Peluso documented, at the local or district level, civil officials - police as well as district and sub-district officers - played direct roles in the enforcement of the forestry departments $\square$ claims to territory and forest resources. District-level administrators or the police, both part of civil administration, were often enlisted to assist in forest protection/guarding activities (Vandergeestand \& Peluso, 2006).

20 State foresters have also taken the advantage of attending international courses and other capacity-building related programs organized through inter-governmental networks, with a large pool of financial and organizational resources (FORDA et.al., 2013).

21 These three epistemologies are different in three respects: first, the term they commonly used to signify their efforts against 'perusakan hutan'; second, political economic interests that evolves around their way of seeing; and third, instutitionalization of methodology they are advocating in their relations to state-enforced knowledge. 
reliance on modern technology. ${ }^{22}$ Acquiring modern technology has allowed these organizations to engage with wider audience. ${ }^{23}$ These organizations works mostly at national and international levels, using alliances to expose environmental incidents such as forest fires and its impacts on biodiversity. They also serve as often-cited sources among civil society networks.

Conservationist groups link deforestation issues with forest degradation. For WWF, deforestation refers to "conversion of forest to another land use or long-term reduction of tree canopy cover. This includes conversion of natural forest to tree plantations, agriculture, pasture, water reservoirs and urban areas; but excludes logging areas, where the forest is expected to regenerate naturally or with the aid of silvicultural measures" (WWF, 2015). WWF's political project revolves around the idea of 'Zero Net Deforestation' by 2020 by phasing out products that derived from deforestation of ecologically important forests. ${ }^{24}$ Greenpeace, meanwhile, used the term 'No Deforestation' interchangeably with 'Zero Deforestation' to label its overarching political objectives.

22 Among them, WWF probably has the longest history of formal involvement in state policy making in Indonesia. WWF was found in 1961 and entered into Indonesia in 1962 as part of WWF International, with the focus on the protection of endangered species in Ujung Kulon, West Java. The organization obtained a legal status as a foundation in 1996. WWF currently manage 14 conservation sites all across Indonesia, mainly in Borneo, Papua, Sumatera, Jawa and Nusa Tenggara, covering around 12 million hectares of terrestrial ecosystem. After five decades of operation, WWF have widened its scope of activities beyond transforming government policy as it engages with business sector through the so-called Market Transformation Indonesia. More than 54,000 supporters support their activities since 2006. Greenpeace, was established in 1971 and started to conduct activities in Indonesia since early 2000.

23 Greenpeace has recently developed the so called 'Kepo Hutan' interactive map, which allows the pubilc to see the most detailed-ever company information, showing the borders of concessions and who owns the concession, and how it relates to peatlands, fire hotspots and deforestation alerts (See Greenpeace Press Release 15 March 2016. http://www. greenpeace.org/international/en/press/releases/2016/Greenpeace-launches-maps-tracking-nearreal-time-Indonesian-deforestation-and-fires/ accessed 5 December 2016

24 The organization has involved intensively in various events involving business sectors at both national and international scales. WWF engage with stakeholders in promoting the protection of areas of high biodiversity and natural carbon storage. The outline of WWF's strategic plan covers detailed targets of must wins areas of conservation and targeted species to protect in Indonesia. This shows how the organization has developed strong methodology to support its political activities (WWF, 2014). 
Current political projects converge into two methodologies: High Conservation Values (HCV) and High Carbon Stock (HCS). $\mathrm{HCV}$ toolkit aims to provide the basis for foresters to simultaneously maintain social and environmental values of wood production through two phases of activities: first, identification of areas inside the forest management unit with exceptionally important social, cultural, or environmental values, and second, implementing a system of management and monitoring to guarantee these values will be maintained or enhanced. ${ }^{25}$ The HCV Toolkit, with the latest 2008 revision, has been increasingly popular to various stakeholders. Reproduction of knowledge is possible through continuous dissemination facilitated by an international governing structure in the HCV Network. ${ }^{26}$ Such activities extract fundings from international governmental organization such as the United Nations Environment Programme, United Nations Development Programme and international donor country such as USAID, as well as from individual contributors when joining training programs. ${ }^{27}$ HCV Network lobbies the government to harmonize regulations among the Ministry of Agriculture, Ministry of Environment and Forestry, Ministry of Agricultural Spatial Planning and the National Land Planning Agency. Such effort is facing contention between

25 This toolkit was originally developed in 1999 as the criteria of certified well-managed forest organized by Forest Stewardship Council (FSC), an internationally recognized certification body established in the United Kingdom. Apart from its introduction in Indonesia, HCV has been used in national and provincial spatial planning in other countries such as Bolivia and Bulgaria. The process of drafting a national interpretation document involved Indonesian and foreign experts in social forestry, anthropology, conservation biology, forest ecology, vertebrate biology and forest production. The document has also been revised by a consortium involving eight member organizations: The Nature Conservancy (TNC), WWF Indonesia, Tropenbos International Indonesia (TBII), the Indonesian Resource Institute (IndRI), Daemeter Consulting, Fauna Flora International (FFI), Conservation International (CI), and Rainforest Alliance (HCV Network, 2008).

26 The network consists of 31 members (environmental organizations, certification agencies, corporations, organizations, the Roundtable of Sustainable Palm Oil, and the Sustainable Agriculture Network). See HCV Network Website https://hcvnetwork.org accessed 13 December 2016.

27 In a HCV assessor licensing scheme, for example, participants pay 12 million rupiah to join a lead assessor training program. 
the Ministry of Environment and Forestry and the Ministry of Agriculture. ${ }^{28}$

High Carbon Stock (HCS) toolkit as introduced by Greenpeace is a methodology to identify areas of land suitable for plantation development and forest areas that can be protected in the long term. Greenpeace assumed the involvement of local communities, whose land use rights and livelihoods, are potentially affected by the ongoing conversion of forest area. ${ }^{29}$ This methodology has been adopted by various palm oil corporations and their supply chain. ${ }^{30}$ The proponents are also struggling to influence the Government of Indonesia to adopt this methodology in formal regulation. However, such effort has not been successful so far. HCS has been responded cautiously, particularly by the Ministry of Agriculture and interest groups affiliated to monoculture plantation industry in Indonesia. ${ }^{31}$ Some big palm oil business, however, adopted the methodology through the establishment of a multistakeholder forum called the Indonesian Palm Oil Pledge (IPOP). ${ }^{32}$

28 The Ministry of Environmental and Forestry proposes an additional category of Essential Ecosystem Areas (KEE) to the proposed HCV areas, which will limit the areas available for further development projects. Such move was interpreted by the Ministry of Agriculture as a barrier to expand socio-economic activities necessary for driving economic growth, in which the expansion of oil palm plantation and other monoculture planting are of importance. See Forum Kelapa Sawit Berkelanjutan, InPOP Technical Inter-Ministerial Taskforce Agrees to Improve Regulations Related to High Conservation Value. In this meeting, it was mentioned that the HCV Consortium for Indonesia guideline will serve as reference when the Government of Indonesia is to discuss the adoption of $\mathrm{HCV}$ in national regulation (FOKSBI, 2016).

29 This methodology was initially developed by Greenpeace, The Forest Truft (TFT), and Golden Agri Resources (GAR), and is now governed by a multistakeholder body called the High Carbon Stock Approach Steering Group, consisting of Greenpeace, Word Wild Fund for Nature, Rainforest Action Network, Forest Peoples Programme, palm oil companies such as Cargill, Golder Agri Resources (GAR), New Britain Palm Oil, Agropalma, Wilmar, Asian Pulp and Paper (APP).

30 To mention some, Cargill, Wilmar, Asian Agri, Musim Mas, Golder Agri Resources, and consumer companies like Unilever, Nestlé, L'Oréal, Delhaize, Kellogg's, Procter \& Gamble, and Johnson \& Johnson are all using the HCS Approach (Greenpeace, 2014).

31 Representatives of the Indonesian Association of Palm Oil Producers (GAPKI) stated in the mass media that it is not necessary for the Government of Indonesia to adopt HCV and HCS, although these two methodologies have been applied in the Roundtable on Sustainable Palm Oil (RSPO) (Agustine, 2014).

32 In September 2014, the Indonesian Palm Oil Pledge (IPOP) was established. It consists of six major palm oil companies accounting for 60 percent out of total crude palm oil output in Indonesia. The signing of the pledge was witnessed by the Indonesian 
The introduction of $\mathrm{HCV}$ and HSV increases political leverage of conservationist groups. At the same time, it is mutually constitutive to the formation of business interests. The introduction of HCS to wider commodity market audience has been accompanied with a shift in their relations with corporations, that is from frontal opposition to a more accomodating approach and engagement as they respond to contemporary political dynamics. ${ }^{33}$ Forestry and plantation business are seeking for wider social legitimacy and market uptake when confronted with sensitive environmental issues that may threaten their market access.

\section{Redistribution}

Redistributive aspect of forestry policies has been a major concern for organizations such as WALHI, Sawit Watch, Oil Palm Smallholders Union or Serikat Petani Kelapa Sawit (SPKS), Transformasi untuk Keadilan Indonesia (TuK INDONESIA), and Forest Watch Indonesia. Redistribution as epistemology of activism is reflected in a wide range of political claims, which centers on fairer access and control over forest land utilization that have long been dominated by forestry conglomerates as a product of state corporatism and oligarchy in the Indonesian forestry sector. Issues such as economic inequality, poverty, social justice, conflict over tenurial access and control, corruption, and the violation of constitutional rights are often found in the way these organizations see deforestation in Indonesia.

Political activism is built upon the knowledge that

Chambers of Commerce (KADIN) as part of the commitment to implement $\mathrm{HCV}$ and HCS methodology. The establishment of IPOP has created strong controversies among different government agencies (particularly between the Ministry of Environment and Forestry, who tends to support President Jokowi's policy to control palm oil expansion, and the Ministry of Agriculture). It also raised the issue of cartel, which was followed by a warning letter from Indonesian Business Competition (KPPU) to conduct investigation. In June 2016, this multistakeholder forum was disbanded (Jati, 2016).

33 One of Greenpeace activist shows her appreciation to companies who joined IPOP and encourages the Government of Indonesia to applaud and promote IPOP as sensible private initiatives. 
deforestation is reproduced under structural constraints facing forest dependent communities in Indonesia as they struggle for access and control over forest resources. It is also a product of governance failure. ${ }^{34}$ WALHI used the term "corporate crime" to emphasize unequal distribution of access and control over forest resource in Indonesia (Z. Suhadi, personal communication, Juni 2, 2016). TuK INDONESIA employed the term "violations of people's constitutional rights" (N. Jiwan, personal communication, June 1, 2016). For Link-AR Borneo, 'deforestation' is associated with terms such as "land grabbing" (D.S. Ifantara, personal communication, June 14, 2016). Forest Watch Indonesia, meanwhile, pointed out the issue of transparency and accountabity of information (C.B. Purba, personal communication, July 22, 2016).

Such understanding has affected the construction of political demands articulated by relevant organizations. WALHI coined the concept of "wilayah kelola rakyat" or "people managed area", arguing that this approach would address the issue of poverty in rural areas where benefits of natural resources utilization are not equally distributed. ${ }^{35}$ Sawit Watch used the tagline 'ecological justice' to frame their normative political orientation. SPKS considers themselves pro 'sustainable palm oil' and has been engaging in the formulation of social criteria in the Roundtable on Sustainable Palm Oil (RSPO) $)^{36}$ that allows smallholders to increase their leverage in the palm oil production chain. TuK INDONESIA use the slogan 'advocating people for justice', which is translated into human rights advocacy and support for initiatives for sustainability related to private and government business, investment, and integrity of agribusiness

34 WALHI is concerned not only with ecologically sound resource management but, more importantly, with the direct link between forests, other natural resources, and the survival of people whose lives depended upon them.

35 This concept is increasingly strategic for WALHI and its political alliances, particularly after President Jokowi committed to transfer 12.7 million hectares of forestland will be transferred to local communities by 2019 as soon as he entered into office in 2014.

36 RSPO is a multistakeholder forum consisting of actors in the global palm oil supply chain. It works on voluntary certification mechanism based on social and environmental criteria. 
commodity trade which connect production and consumption with human rights and social justice. ${ }^{37}$ Political activism is embedded in a wider agenda of agrarian reform, where issues such as sustainable forest governance, legal enforcement to protect constitutional rights of the people are of priority. Reproduction and dissemination of knowledge is facilitated by transnational and international donors, ${ }^{38}$ contribution of conservationist organization in research and advocacy activities, ${ }^{39}$ and strategic collaboration with university experts. $^{40}$

A complementary strategy is to push for greater financial support to smaller business actors that allows equalization of levels of playing fields. For SPKS, the promotion of new oil palm planting offers economic opportunities as long as knowledge on palm oil planting and plantation management, technical expertise, and financial access to small farmers are accessible to smallholders. In addition to land use rights reform, SPKS is concerned with economic empowerment that will reduce economic dependence of independent oil palm smallholders on their corporate partners. Consolidation of knowledge is also strengthened by the development of standard operating procedures on Good Agricultural Practices (GAP) in palm oil industry.

37 See Transformasi untuk Keadilan INDONESIA (TuK INDONESIA) website: http:// www.tuk.or.id

38 Forest Peoples Programme (FPP) has been known for supporting community-based environmental programs that allows local communities to strengthen their capacity in participatory mapping and sustainable environmental resource management.

39 As seen in the profile of funding institutions enlisted in the publications of these CSOs.

40 There are varieties of methodology developed to translate redistributive epistemology into political activism that links these organizations with grassroots constituents. Participatory mapping becomes a common strategy to embrace grassroots participation, which involves the documentation of local communities knowledge on resources that have supported their livelihoods and to define the boundaries of their claim into a systematic description. The formation of Konsorsium Pendukung Sistem Hutan Kerakyatan (KpSHK) or Consortium on Supporting Community Forest System established in 1997, and Jaringan Kerja Pemetaan Partisipatif (JKPP) or Participatory Mapping Working network are some examples. 


\section{Indigeneity}

Indigeneity refers to "permanent attachment of a group of people to a fixed area of land in a way that marks them as culturally distinct" (Li, 2010, p.385). The prominence of indigeneity has been a central issue for customary communities, whose entitlements to land rights in Indonesia was curtailed during the New Order era as the national government imposed uniformity in political administration at the village level. ${ }^{41}$ Organizations who share the importance of cultural distinction are AMAN, Institute Dayakologi, and to a certain extent, Pancur Kasih. For these organizations, indigenous knowledge is instrumental in the reproduction of indigeneity that promote claims and entitlements over land rights. It also functions as a tool of differentiation between those who are 'indigenous' and those who are not.

There is an evident link between instrumentalization of indigenous knowledge and political mobilization among customary communities to increase political leverage. ${ }^{42}$ Solidarity making has been part of costumary communities' struggle since the New Order era, but only in the Post-Suharto era they gain stronger momentum that resonates political demands. In 1999, civil society

41 In 1979, Suharto enacted Law No.5/1979 on Village Governance Law. 60,000 villages were required to adopt a governance structure modeled after Javanese villages regardless of their cultural and institutional diversity at the local level. For national policy makers at that time, this uniformity was to act as a precondition for successful national development as well as to support intensive upgrading and control (Bebbington, Dharmawan \& Fahmi, 2006).

42 There were attempts to accumulate indigenous knowledge collectively using interorganizational resources. In West Kalimantan, Institute Dayakologi is known for its efforts to document traditional wisdom and values among various Dayak communities in managing natural resources. Kalimantan Review, a regular publication produced by Institute Dayakologi, has been the site of articulation of Dayak's view on socioeconomic, political and environmental issues. It gained quite a broad audience nationally and internationally when it was first established, but was until recently closed due to minimum circulation. The institute is also affiliated to Pancur Kasih Credit Union, which activities focuses on strengthening economic resilience of Dayak communities in response to modern industrialization policies, particularly in the forestry and agricultural sector. The modernization of credit union in West Kalimantan that serves the need to empower Dayak communities, is an example of how the interaction between traditional knowledge and modern, professional business management is increasingly recognized and is beneficial for the purpose of organizing wider political support. 
and some indigenous peoples leaders and advocates organized the first national Congress attended by twelve national and grassroots organizations. The Alliance of Indigenous People of the Archipelago (AMAN) was formed as a result of the meeting (Affif and Lowe, 2007). Coalitions of civil society have attempted to elevate their struggles on customary rights recognition by connecting various localities. Their efforts was fruitful when in May 2013, AMAN with the support of environmental and agrarian activists were able to pushed the government to enact Constitutional Ruling Number 35/ PUU-X/2012, which separated the legal status of customary forest from state forest. ${ }^{43} 44$

Political agenda converges around lobbying to introduce local government regulation that protects indigenous peoples' rights. This movement was initiated mostly by several Dayak groups having close connections with political parties. They rely on legal experts from local universities, who provide advice to strengthen political arguments. A study by De Royers et al argued that the use of the term very often lead to puritanism if it is seen as the prerogative of customary law communities at the expense of in-migrating forest dwellers (De Royer, Visser, Galudra, Pradhan, \& Van Noordwicjk, 2015).

Networking among indigenous communities through regular personal communications and knowledge-sharing forums allows Dayak communities to link various aspects of their struggles, including legal protection to Dayak community members who are

43 Indonesia's Constitutional Court has accepted the Judicial Review of some parts of Act No. 41/1999 on Forestry (Undang-Undang Kehutanan or UUK), declaring that customary forests should not be classed as "State Forest Areas." This comes as a response to a petition submitted by the Indigenous Peoples' Alliance of the Archipelago (AMAN) in March 2012. Ruling No. 35/PUU-X/2012 separates customary forests from their previous classification as State forests. Indonesia's 1999 Forestry Law previously stated that "customary forests are state forests located in the areas of custom-based communities". The Constitutional Court's ruling deletes the word "state" from that sentence, and revises the Law so that state forests no longer include customary forests.

44 This means customary community has stronger rights in natural resource management. This legal momentum is used by various customary communities in West Kalimantan to push for local government legislation that may increase their political leverage. 
involved in legal conflicts with the state or corporations (S. Masiun, personal communication, June 14, 2016). Reproduction of cultural sentiments are also seen in the way activists and their affiliated organizations as an emerging collective identify themselves with particular place that associate them with specific cultural wisdom (S. Sampurna, personal communication, June 11, 2016). There has been attempts to accumulate, document, and consolidate knowledge on Dayak culture by forming transnational research network, such us through the idea of establishing Borneo Studies Center (B. Efrain, personal communication, June 13, 2016).

Recent 'One Map' policy introduced by President Joko Widodo realigns customary communities with the wider groups. ${ }^{45}$ Most indigenous people organizations expressed their commitment to participatory mapping as an important tools of knowledge claim. There is, however, complexities in sustaining close engagement between grassroots constituents, representing organizations and political representatives in the parliament or in the state bureaucracy, thereby creating disconnections in the pronouncement of indigeneity agenda.

\section{Reconfiguring 'Deforestation'}

The emergence of three contesting epistemologies and their rendition into a wide range of political activisms needs reading beyond simply inclusion and exclusion by dominant powers. It is a formation of political agency in which alternative ways of seeing are trying to subvert any attempt to dominate state-construed epistemology. While there is no literal adoption of 'deforestation' in the forestry law, recent development witnessed the inclusion of the term at the lower hierarcy of state regulation, i.e., in Presidential Decrees and Ministry of Forestry Decrees. Former Minister of

45 Indonesia's One Map policy is stipulated in Law No. 4/2011 on geospatial information and was launched to help resolve disagreements resulting from the use of different data and maps that often cause land disputes and overlapping permits for plantation and mining operations. 
Forestry, H.M.S Kaban, issued the Minister of Forestry Decree No.68/2008 on the Implementation of Demonstration Activities on Reducing Emission from Deforestation and Forest Degradation (REDD). ${ }^{46}$ Subsequent regulation was issued under the Minister of Forestry Decree No. 30/2009 on the Implementation Procedures of Reducing Emissions from Deforestation and Forest Degradation (REDD). Here, deforestation is defined as permanent alteration from forested area into a non-forested area as a result of human activities. In line with this definition is the term 'forest degradation'. In the Minister of Forestry Decree No. 30/2009, 'forest degradation' means the deterioration of forest cover quantity and carbon stock during a certain period of time as a result of human activities. The main causes of forest degradation included in this definition are unsustainable logging, agriculture (shifting cultivations), fires, fuel wood collection, and livestock grazing, which have various impacts of degradation level. The Presidential Decree 62/2013 on The Establishment of Agency to Regulate Greenhouse Gases Emission from Deforestation, Forest Degradation and Peatlands stated that forest is specific area designated by the government to be preserved, while deforestation is defined as permanent change from forested area to unforested area.

Each epistemic position as discussed in previous section have their own advantage in terms of how associated actors capitalize interorganization networks as part of political mobilization and how this helps the accumulated knowledge to infliltrate into decision-making process. Conservationist organizations are largely able to build strong network with resourceful transnational counterparts. This is very useful in strengthening their leverage in the national policy

46 This Regulation was issued following the 13th Conference of the Parties to the UNFCCC (COP-13) in Copenhagen. It regulates the possible proponents of demonstration activities as government, forest timber product utility license holders, holders/managers of right forests, managers of customary forest, and heads of forest management units. Partners may be government, international organizations, private entities and individuals. The objective is specified as obtaining forest management design related to the achievement of this aim. 
making. When engaging in the debate on Reducing Emission from Deforestation and Forest Degradation (REDD), especially when the state has to deal with international pressure to respond to REDD issues and global climate change mitigation agenda. Redistributive groups see their relations with the state more ambiguously. Although most of civil society organizations within this category have strong basis in the grassroots, they hardly posses sufficient political capital to increase their leverage in the formal politics. ${ }^{47}$ Conglomeration and oligarchy in the forestry sector remains to present structural constraints when these groups seek opportunities to level their political playing field using 'democratization of natural resource governance' imperative aligned with political decentralization. Groups advocating indigeneity often stand in a similar front with the redistributive groups on various issues, yet emphasizing the importance of recognizing cultural distinction as part of policy reform.

Most political strategies to transform 'deforestation' are oriented towards changing state forestry policies. Activists mostly target The Ministry of Forestry ${ }^{48}$ and the People's Representative Council (DPR) (the main Indonesian national legislature), the Ministry of Environment and the National Land Planning Agency in their advocacy (Di Gregorio, 2014). With the seemingly more accomodating approach by state, civil society organizations and activists take the advantage of having access to bureaucratic policy making as a means to articulate specific political demands. This applies to small segments of activists who have close connections to state elites at national and local levels, be it a result of personal networking or as a product of institutional appointment. In the

${ }_{47}$ Most of interviewees express their reluctance to engage with formal representation mechanisms through political election.

48 The most powerful unit within the Ministry of Forestry is the Directorate for Forest Utilization. It controls the revenue flow from logging concessions and other forest fees and contributes roughly $1 \%$ of the total revenue of the Indonesian Government. Its main priority is to advance large-scale forest exploitation for national development aims, and while sustainability standards exist, they are only weakly enforced (see Di Gregorio, 2014). 
aftermath of forest fires in 2015, President Joko Widodo (also known as Jokowi) established 'Peatlands Restoration Agency, consisting of various civil society actors, including academia and environmental NGOs. Most of the members of this task force are academia and scientists who share strong conservationist value. They are also well known for their scientific reputation or environmental activism. The purpose of this task force is to coordinate national policy on peatlands restoration by mapping out the areas under category of peatlands. ${ }^{49}$

In dealing with epistemological divide, there were attempts to nurture common political agenda through tactical coalitions. This appeared in in the era of President Susilo Bambang Yudhoyono (2004-2014) and President Jokowi (since 2014). The formation of 'Civil Society Coalition for the Protection of Indonesian Forest and Global Climate' or “Koalisi Masyarakat Sipil untuk Penyelamatan Hutan Indonesia dan Iklim Global' is one of a kind. ${ }^{50}$ After President Yudhoyono announced the moratorium policy as part of Letter of Intent with the Norwegian government in May 2010, this coalition established a common platform in October 2010 to show their political standing. ${ }^{51}$ This platform seeks to articulate forest restoration and conservation in line with Free Prior Informed Consent (FPIC). The redistributive aspects is represented in the demand that the moratorium policy to cover not only new business licenses, but also review on the ongoing licenses, as well as the importance of designing dispute settlement mechanisms to address the roots of social and agrarian conflict. ${ }^{52}$ This coalition has been

49 The head of the agency, Nazir Foead, is a well-known environmental activist. He is formerly the conservation director at the World Wildlife Fund (WWF).

50 This coalition links conservationist NGOs with coalitions of indigenous communities and organizations working on wide aspects of forestry sector reform and Indonesian policy on climate change.

51 Conservationist NGOs have lobbied for this policy since the era of President Megawati, yet did not gain sufficient political momentum.

52 This common platform includes Walhi, HuMa (Coalition for Community and Environmentally-Based Legal Reform) BIC (Bank Information Center), Sawit Watch, KpSHK, Forest Watch Indonesia, CSF (Civil Society Forum for Climate Justice), ICEL (Indonesia Center for Environment Law), AMAN, JKPP, SP (Solidaritas Perempuan 
also been active in the debate around the revision of Government Regulation 71/2014 on Peat Ecosystem Management and Protection which was completed in 2 December 2016 with the introduction of Government Regulation 57/2016. ${ }^{53}$

Another tactical coalition is the Anti Forest-Mafia Coalition, which has been active in responding to corruption issues in the forestry sector. ${ }^{54}$ Financed by international donor organizations, this coalition conducted several studies that aim to provide input for Jokowi's government in terms of implementing more sustainable forest policies. These publications also contain criticism to the existing forestry governance. ${ }^{55}$ In addition to that, the presence of Eyes on the Forest, a coalition of three local environmental organizations in Riau, Sumatra, Indonesia: WWF Indonesia's Tesso Nilo Programme, Jikalahari ("Forest Rescue Network Riau") and Walhi Riau (Friends of the Earth Indonesia), also demonstrated an

Women's Solidarity for Human Rights, and Greenpeace. (Walhi et. al., 2010).

53 The main point of the revision is that there should be no land clearing and no issuance of new licenses in peatland areas, especially for deep peatland. The regulation also stated that no drainage should be performed as it causes the peat to dry out, and no fires can be set in peatland areas. Even traditional communities have been barred from setting fires in peatland areas. It places a permanent moratorium on peatland exploitation, stating that everyone is prohibited from clearing new land until a zoning system for the protection and cultivation of the peatland ecosystem is in place. By 2016, members of this coalition have increased to 20 organizations: 1. Greenpeace Indonesia, 2. Indonesia Center for Environmental Law (ICEL), 3. Yayasan Pusaka, 4. Forest Watch Indonesia, 5. HuMA, 6. JIKALAHARI - Riau, 7. Serikat Petani Kelapa Sawit (SPKS), 8. Hutan Kita Institut (HaKI) - Sumatera Selatan, 9. Save Our Borneo (SOB) - Kalimantan Tengah, 10. Sawit Watch, 11. Badan Registrasi Wilayah Adat (BRWA), 12. AMAN (Aliansi Masyarakat Adat Nusantara), 13. Konsorsium Pendukung Sistem Hutan Kerakyatan (KPSHK), 14. Jaringan Kerja Pemetaan Partisipatif (JKPP), 15. Debt Watch, 16. Yayasan Merah PutihCentral Sulawesi, 17. KKI-Warsi- Jambi, 18. Yayasan Paradisea-Manokwari, 19. Yayasan Madani, 20. Epistema.

54 This coalition consists of Auriga Nusantara (non-governmental organization that engages in an effort to conserve Indonesian natural resources and the environment), Jikalahari (NGO forest network based in Pekanbaru, Riau Province), Indonesian Corruption Watch (ICW), Indonesian Forum for Budget Transparency (FITRA), and Indonesia Center for Environmental Law (ICEL), WALHI, WWF-Indonesia, Indonesian Working Group on Forest Finance, Silvagama, Transparency International Indonesia, and GAPETA Borneo (Kalimantan Forest Monitoring NGO), and RPHK (Kalimantan Forest Monitoring Volunteers).

55 See among others Forest-Trends and Anti-Forestry Mafia Coalition (2015) and AntiForestry Mafia Coalition (2014). 
attempt to sustain collective action. ${ }^{56}$ Other coalitions were formed in response to environmental incidents such as alleged deforestation policy breach by alleged forest corporation, which was claimed to contradict sustainability policy that has been declared in public. Although started in a small local network, knowledge claim produced by this ad hoc coalitions was able to gain attention at transnational level. ${ }^{57}$

Mobilization of activists from one organization to another has allowed more densed inter-personal networks and wider knowledge dissemination, but it may not necessarily translate into well-consolidated political struggles. Political competition among activists and organizations to pursue particular interests were often counterproductive and co-opting to the formation of collective struggle. This is particularly true when there is lack of definition of what constitute collective agenda. When not addressed, this may further undermine the coherence of the movements.

\section{Conclusion}

This research has discussed three epistemological positions (conservation, redistribution, and indigeneity) which are constitutive in reproducing the term 'deforestation' in state-enforced forestry policies in Indonesia. Appropriation of scientific forestry by the state translated into authoritative mapping of forest zones serves as a basis of distributing access and control over forest resource

56 Eyes on the Forest have built their own website, with well-documented chronological activities to support their campaign. The website consists of several important headings that cover news, press release, publications, investigation reports, photos and videos that expose unsustainable practices by companies under their scrutiny. See $h t t p: / / w w w$. eyesontheforest.or.id

57 In June 2015, network of organizations consisting of Eyes on the Forest, Global Forest Watch, Gapeta Borneo, WWF-Indonesia East Kalimantan Program exposed irregularities of sustainability policy implemented by one giant pulp and paper company, Asia Pacific Resources International Limited (APRIL). The issue was on the clearance of peatland by the company's supplier. After released in the Eyes on the Forest Website, the statement soon widely spread out in the website of the network and is circulated internationally. The use of technology such as NASA Landsat Images in the news coverage by Mongabay.com (an environmental science and conservation news and information site) was evident in strengthening claim regarding legal violation by the company (Butler, 2015). 
utilization and commodification to commercial entities. Within the civil society movements, efforts to increase political leverage is probably most evident in the way actors challenge state-imposed zoning and produce alternative conceptions of territories through specific methodologies, such as $\mathrm{HCV}, \mathrm{HCS}$, and participatory mapping.

Rather than produced around a relatively stable set of differences along clear cut epistemological boundaries, collective action is a result of continuous renegotiation among various epistemological positions as they attempt to subvert and appropriate state knowledge over deforestation. Tactical alliances among the proponents of diverse epistemologies remain to be prominent amidts structural constraints that thwart the movements. Knowledge co-production redefines the permeable boundaries of political struggles, transcends different epistemologies and affects political mobilizations across different civil society organizations and individual activists. Depoliticization persists in the absence of an open debate as regards to how such epistemological differences would affect political orientation of civil society movements, an immediate issue to be addressed collectively. 


\section{References}

Affif, S., \& Lowe, C. (2007). Claiming indigenous community: political discourse and natural resource rights in Indonesia. Alternatives, 3(1), 73-97.

Agarwal. A. (1995). Dismantling the divide between indigenous and scientific knowledge. Development and Change, 26, 413-439.

Agustine, I. (2014, December 13). GAPKI Nilai Skema HCV dan HCS Tidak Penting Bagi Indonesia. Bisnis. Retrieved from http:// industri.bisnis.com/read/20141213/99/382219/gapki-nilaiskema-hcv-hcs-tidak-penting-bagi-indonesia

Barber, C.V. (1998). Forest Resource Scarcity \& Social Conflict in Indonesia. Environment: Science and Policy for Sustainable Development, 40(4), 4-37.

Bebbington, A., Dharmawan, L., \& Fahmi, E. (2006). Local Capacity, Village Governance, and the Political Economy of Rural Development in Indonesia. World Development, 34(11), 1958-1976.

Borras Jr, S. M. (2006). Redistributive land reform in 'public' (forest) lands? Lessons from the Philippines and their implications for land reform theory and practice. Progress in Development Studies, 6(2), 123-145.

Boudia, S., \& Jas, N. (2014). Powerless Science? Science and Politics in a Toxic World. New York: Berghahn.

Butler R. A. (2015, March 26). APRIL Violates Sustainability Police by Clearing Peat Forest after Jan Cut Off. Mongabay. Retrieved from https://news.mongabay.com/2015/03/april-violatessustainability-policy-by-clearing-peat-forest-after-jan-cut-off/

Di Gregorio, M. (2011). Social Movement Networks, Policy Processes, and Forest Tenure Activism in Indonesia. Doctoral Thesis. London: London School of Economics and Political.

Di Gregorio, M. (2014) Gaining Access to the State: Political Opportunities and Agency in Forest Activism in Indonesia. Social Movement Studies: Journal of Social, Cultural and Political Protest, 13(3), 381-398.

De Royer, S., Visser, L.E., Galudra, G., Pradhan, U., \& Van Noordwicjk, M. (2015). Self-identification of indigenous people in post-independence Indonesia: a historical analysis in the context of REDD+. International Forestry Review 17 (3), 1-16.

FOKSBI. (2016, May 3). InPOP Technical Inter-Ministerial Taskforce Agrees to Improve Regulations Related to High Conservation Value. FOKSBI. Retrieved From: http://www.foksbi.id/id/berita/ 
baca/05-03-2016-inpop-technical-inter-ministerial-taskforceagrees-to-improve-regulations-related-to-high-conservation-value

FORDA, CIFOR, ICRAF and Tropenbos. (2013). Forestry research Collaboration Between FORDA and Partners. Jakarta: Forestry Research and Development Agency (FORDA), pp.8-14.

Forsyth, T. (2003). Critical Political Ecology: the Politics of Environmental Science. London: Routledge.

Forsyth, T. (2008). Political ecology and the epistemology of social justice. Geoforum, 39(2), 756-764.

Greenpeace. (2014). The High Carbon Stock Approach [Briefing Paper]. Author, Retrieved from http://www.greenpeace.org/international/ Global/international/briefings/forests/2014/HCS $\% 20$ Approach_Breifer_March2014.pdf

Greenpeace. (2016, March 15). Greenpeace launches maps tracking near real time Indonesia deforestation and fires [Press Release]. Author. Retrieved from http://www.greenpeace.org/international/en/press/ releases/2016/Greenpeace-launches-maps-tracking-near-realtime-Indonesian-deforestation-and-fires/

Haenn, N. (2016). The Middle Class Conservationist: Social Dramas, Blurred Identity Boundaries, and Their Environmental Consequences in Mexican Conservation. Current Anthropology, 52(2), 197-217.

HCV Network, (2008), Toolkit for Identification of High Conservation Values in Indonesia, Retrieved from: https://www.hcvnetwork. org/resources/national-hcv-interpretations/HCV\%20Toolkit $\% 20$ for\%20Indonesia-Engversion-final.pdf.

Jasanoff, S. (2004). States of Knowledge: the Co-production of Science and Social Order. London: Routledge.

Jati, G. P. (2016, August 01). IPOP Bubar, Enam Konglomerat Sawit Dukung Ispo Pemerintah. CNN Indonesia. Retrieved from: https:// www.cnnindonesia.com/ekonomi/20160701145817-85-142442/ ipop-bubar-enam-konglomerasi-sawit-dukung-ispo-pemerintahah

Jong, H.N. (2015, August 21). Customary Land Included in One-map Policy. Jakarta Post. Retrieved from http://www.thejakartapost. com/news/2015/08/21/customary-land-included-one-mappolicy.html

Joshi, L., Wijaya, K., Sirait, M., \& Mulyoutami, E. (2004). Indigenous systems and ecological knowledge among Dayak people in Kutai Barat, East Kalimantan -a preliminary report. ICRAF Southeast Asia 
Working Paper, Bogor: ICRAF

Kareiva, P., \& Marvier, M. (2012). What is conservation science. BioScience, 62(11), 962-969.

Karimasari, N. (2011). Transnational Environmental and Agrarian Movements Influencing National Policies: The Case of Palm Oil Plantation in Indonesia. Research paper. Hague: Institute of Social Studies.

Kurniawan, N.I., \& Rye, S.A. (2014). Online Environmental Activism and Internet Use in the Indonesian Environmental Movement. Information Development, 30(3), 200-212.

Leach, M., \& Scoones, I. (2007). Mobilizing Citizens: Social Movements and the Politics of Knowledge. Brighton: Institute for Development Studies.

Li, T.M. (2001). Masyarakat Adat, Difference, and the Limits of Recognition in Indonesia's forest zone. Modern Asian Studies, 35(3), 645-676 .

Li, T. M. (2010). Indigeneity, Capitalism, and the Management of Dispossession. Current Anthropology, 51(3), 385-414.

McCarthy, J. F. (2005). Between Adat and State: Institutional Arrangements on Sumatra's Forest Frontier. Human Ecology, 33(1), 57-82.

Nomura, Ko. (2007) Democratisation and Environmental NonGovernmental Organisations in Indonesia. Journal of Contemporary Asia, 37(4), 495-517.

Okamoto, S. (2001). The Movement and Activities of Environmental NGOs in Indonesia. Policy Trend Report, pp. 13-23.

Peluso, N. (1992). The Political Ecology of Extraction and Extractivism in East Kalimantan, Indonesia. Development and Change, 23(4), 49-74.

Peluso, N.L. (1995). Whose Woods are These: Counter-Mapping Forest Territories in West Kalimantan, Indonesia. Antipode, 27(4), 388392.

Peluso, N.L. (1995). Whose Woods are These: Counter-Mapping Forest Territories in West Kalimantan, Indonesia. Antipode, 27(4), 383406.

Perry, David A. (1998). The Scientific Basis of Forestry. Annual Review of Ecology and Systematics, 29, 435-466.

Schmitt, C. (1976). The Concept of the Political, New Brunswick, NJ: Rutgers University Press.

Spilsbury, R. (2010). Deforestation Crisis. New York: The Rosen Publishing Group.

Suwarno, A., Hein, L., \& Sumarga, E. (2015). Governance, Decentralisation 
and Deforestation: the Case of Central Kalimantan Province, Indonesia. Quarterly Journal of International Agriculture, 54(1), 77100.

Turner, S. (2007). Political Epistemology, Experts, and the Aggregation of Knowledge. Spontaneous Generations, 1(1), 36-47.

Undang Undang RI tentang Ketentuan-Ketentuan Pokok Kehutanan 1967. No. 5, Retrieved from http://sipongi.menlhk.go.id/cms/ images/files/1021.pdf

Undang Undang RI tentang Kehutanan 1999, No. 41, Retrieved from http://prokum.esdm.go.id/uu/1999/uu-41-1999.pdf

Undang Undang RI tentang Pencegahan dan Pemberantasan Perusakan Hutan 2013, No. 18, Retrieved from http://www.dpr.go.id/ dokjdih/document/uu/UU_2013_18.pdf

Vaccaro, I., Beltran, O., \& Paquet, P.A. (2013) Political Ecology and Conservation Politices: Some Theoretical Genealogies. Journal of Political Ecology, 20(20), 255-272.

Vandergeest, P., \& Peluso, N.L. (2006). Empires of Forestry: Professional Forestry and State Power in Southeast Asia, Part 1. Environment and History, 12(1), 31-64.

Vandergeest, P., \& Peluso, N.L. (2006). Empires of Forestry: Professional Forestry and State Power in Southeast Asia, Part 1. Environment and History, 12(1), 42.

Walhi, et. al. (2010, October). Platform Bersama untuk Penyelamatan Hutan Indonesia Indonesia dan Iklim Global. Retrieved from www. greenpeace.org/seasia/id/PageFiles/110812/Indonesia\%20 CSOs\%20common\%20platform\%20-11OCT.pdf

WWF. (2015, April 27). Living Forests Report Chapter 5: Saving Forest at Risk. Author. Retrieved from http://www.worldwildlife.org/ publications/living-forests-report-chapter-5-saving-forests-at-risk

WWF. (2014). WWF Indonesia Strategic Plan 2014-2018. Author. Retrieved from http://awsassets.wwf.or.id/downloads/wwfid_ strategicplan_2014_2018_summary_final.pdf 